\title{
The Speech Act of Rebuke in Indonesian Students' Interaction
}

\author{
Ratna Susanti $^{1,2, *}$, Sumarlam ${ }^{1}$, Djatmika ${ }^{1}$, Muhammad Rohmadi ${ }^{1}$ \\ ${ }^{1}$ Sebelas Maret University of Surakarta, Indonesia \\ ${ }^{2}$ Politeknik Indonusa Surakarta, Indonesia
}

Received August 9, 2019; Revised October 18, 2019; Accepted October 25, 2019

Copyright $\bigcirc 2019$ by authors, all rights reserved. Authors agree that this article remains permanently open access under the terms of the Creative Commons Attribution License 4.0 International License

\begin{abstract}
This research was conducted with the aim of investigating rebuke speech acts in student interactions during practicing class using pragmatic approach and politeness strategies. Human beings can never be separated from the use of oral language in the form of speech acts. One of the interesting events to study and analyze language pragmatics is by observing how students relate in academic environments. This is necessary due to the importance of speech act in communication through the use of spoken language. This research was conducted qualitatively using a pragmatic theory approach and 100 students participating in a practical class were selected randomly as subjects of the research. The data used include the students' speeches during the violation of practice procedures in the laboratory and the data collection techniques used were open questionnaires through the Discourse Complete Test (DCT) involving 10 types of real situations. The data obtained were analyzed using Searle's speech act and Brown and Levinson's politeness strategy theories. The results indicated the existence of greatest tendency for rebuke expressive speech acts, which violate politeness strategies.
\end{abstract}

Keywords The Speech Act of Rebuke, Pragmatics Analysis, Student's Interaction

\section{Introduction}

Class interactions include language activities and, according to Searle [1], these involve the use of several speech acts such as being grateful, asking for help, and making orders in accordance with the rules of language elements usage. Speakers are not only required to use grammatical language but are also required to ensure the words are accepted in the community [2]

An Indonesian speaker does not always use the imperative during interactions, but also interrogative forms.
The selection of one sentence formulation contains different effects on the speakers and speech partners. This shows language does not only function to express cognitive elements but also to reveal the attitudes existing in a language. However, in certain conditions, these elements of attitude are not explicitly stated by the speaker but understood by the speech partner.

The meanings underlying speech acts can be divided into three and they include locutionary, illocutionary, and perlocutionary act. The follow-up locutionary act relates to the grammatical formation of prepositions and references or points to meaning. In the act of locution, speakers clearly explain or provide information about a certain thing without any other intent or meaning. However, illocutionary speech acts contain statements with hidden meanings while the perlocutionary ones involve the effect or result of a speech. In this case, the speaker expects the speech partner to capture the meaning intended. Among these three, illocutionary act has received much attention from this paper [3], and it was divided into five types including assertive, directive, commissive, expressive, and declaration speech acts. All of these have a close connection to the practical classroom interactions for students on the polytechnic campus with each of them playing important roles.

Polytechnic is a higher institution of education characterized with the use of practical more than the theoretical courses. In the structure of higher education in Indonesia, polytechnics have a significant role in producing quality graduates with the readiness to enter the business and the industrial world effectively. This due to the provision of several skills according to fields of competence to the students through the use of more practical subjects. One of the polytechnics in Indonesia is the Polytechnic Indonusa of Surakarta which has a Pharmacy study program.

Language is a very important tool for communication by students during activities in the practical classroom. This is 
observed in the guideline provided that all students must comply with various Standard Operating Procedures (SOPs), before, during, and after the practice. These SOPs are implemented to maintain fluency in practice and to avoid mistakes that could lead to workplace accidents. However, several cases of intentional violations are reported directed towards reducing operational procedures despite the potentially fatal impact it may have on the violator, colleagues, and the failure of the whole practical. Based on this phenomenon, this research was conducted to examine several speech acts used by students when their friends make mistakes incompatible with the SOPs during practice and to achieve this students' speech acts were varied due to the difference in communication abilities.

Communication skills consist of two aspects of linguistic and sociolinguistic abilities both of which are further supported by grammatical ability, sociolinguistic abilities, literacy skills, and communication strategy abilities [4] to determine the success of communication between speakers and speech partners. In line with this, the aim of this study was to describe the form and function of speech acts between students in practical classroom interactions at the Polytechnic Indonusa of Surakarta laboratory, especially when the SOPs are violated by colleagues as well as the strategies used to rebuke speech acts. Students of vocational department's level of politeness were dominantly observed to simultaneously indicate cost and benefit scale instead of an indirect scale. For example, a sarcasm speech made by the lecturer shows a thoughtful meaning.

Lecturer: "Yusuf, kamu kok ganteng sendiri to, yang lain pakai wear pack. Kamu kok pakai kaos?” [Yusuf, how come you are the most handsome of the others and while others wear other clothes, how come you wear a shirt?]

This statement clearly reflects the insulting pragmatics used by the lecturer on a student, Yusuf, which was caught not wearing lab-coat in the work. In the context of Javanese culture, lecturers are traditionally considered more mature and knowledgeable than the students. As a realization of respect, students need to be polite to their lecturer(s). Politeness acts relate the language addressed the various aspects of social norms and structures as well as behavioral and ethical rules application. Students' utterances to lecturers in academic activities are inevitably inseparable from politeness issues. In addition to being influenced by the Javanese cultural context, politeness both realizations and strategies are also influenced by a paradigm shift in learning from teacher-centered to learner-centered. This change in paradigm has an impact on the changes in patterns of interaction between students and lecturers within an interaction which engages various academic activities. This interactional pattern influences their politeness language-style realization and strategies. Those academic activities are all things related to campus activities, such as discussions both inside and outside the classroom, consulting academic advisers, consulting reports and practicum, guiding final project proposals, etc. [5]

Interaction among students in polytechnic as a social group and in academic activities involve the application of certain principles and one of the social rules is politeness [6]. In this study, the data were analyzed with focus on the following questions: (1) What speech act of rebuke pattern is used by students on others when procedures are violated; (2) What is the rebuke strategy used by students on others when procedures are violated in practical classes?

\section{Literature Review}

\subsection{The Speech Act Theory}

The speech act is a theory of language put forward by Austin [7] and in contrary to linguistics and semantics which are restricted to the linguistic structures created, it also considers the non-linguistic communication situations. Austin [7] in this regard focuses on the relationship between language and act This means it focuses on the relationship between language and act such that while using language, action is also required instead of the production of only isolated series of sentences. This implies the use of language involves stimulation of some form of actions such as thanking, requesting, promising and others. With the application of philosophical approach to speech acts, Searle studied isolated sentences or fabricated utterances issued in a given context and more insight was provided using discourse analysis which analyzed the concept, not in isolation, as observed in philosophy or pragmatics, but in sequences occurring in natural discourses [8]

Another researcher [9] showed that a speech act is presented in real language use situations by basically assuming the smallest unit in human communication is the implementation of certain types of acts which are further associated with the functional dimensions of language. In contrary to the morphological, syntactic and rhetorical dimensions regarding the organization of the language structures, the pragmatic dimension is associated with producing and understanding speech acts and these function reciprocally in communication [10]. Moreover, the constantive used in describing an incident or a situation, are statements and qualified as true or false values. However, it is mostly used to perform a task that makes it impossible to characterize it as true or false and this made Searle felt particularly attracted to performatives [11].

Theories of speech acts emphasize both linguistic and social aspects of language and its use. Yule [12] also reported it involves action performed via utterances and according to its nomenclature, speech is the utterance while act is the action. This means it is only about saying something but also doing something [9]. Thus, it is more 
than describing a word, it involves communicating, passing information, and more than mutual acting between the speaker and the speech partner. One of the aspects studied in pragmatics is a speech act and it was defined by Yule [12] as the action performed by a speaker with an utterance. This shows when speaker says something, there are several activities attached to the statement. Moreover, as stated in the introductory part, speech act is divided into three different acts including locutionary, illocutionary and perlocutionary, and it is divided into assertive, directive, commissive, expressive and declarations by Searle further [13]. This means that in uttering a sentence, three kinds of acts are simultaneously performed, a locutionary act which presupposes the utterance of a sentence with determinate sense and reference, i.e. the study of meaning; an illocutionary act which presupposes the making of a request, statement, promise, offer, asking a question, issuing an order, etc, i.e., the direct achievements by the conventional force associated with the issuance of an utterance; and a perlocutionary act which presupposes the bringing about of effects on the addressee(s) depending on the circumstances of the utterances, i.e., all the intended and unintended effects or consequences caused by a particular utterance in a particular situation [8].

\subsection{Language Politeness Strategy}

Language politeness is reflected in the procedures used in communicating through verbal signs or language in accordance with the cultural elements existing in the community. It is expected that individuals speak politely to realize effective communication because the use polite, systematic, orderly, clear, and straightforward language reflects the virtue possessed by the speaker [6].
Sociocultural norms require that humans be polite in interacting with each other. It is important to point out that communication requires both verbal and nonverbal behaviors. Verbal behavior involves imperative functions such as speaker's expression of commands, necessities, or prohibitions to the speech partner while nonverbal includes the accompanying physical gestures.

Politeness principle is also registered in expressive speech acts functioning as illocutionary of rebuke used in situations involving expression of the desire to share the sorrow over some sad events, loss, grief, tragedy, etc. The politeness of such speech acts is relative to the situation, atmosphere of formality, sincerity of communication, relationship, and social distance. Brown and Levinson [14] reported there are two types of politeness, negative and positive such that negative politeness avoids offense by showing deference, whereas positive avoids it by highlighting friendliness. These depend on the attention of the speaker to own and listener's face wants. However, the face is interpreted as a personal attribute with constraint on social interaction while face wants are the desire to protect the positive and negative face from any threat [15]. Put differently, the face is one's self-esteem granted by others in a community and any speech act with the potential to threaten speakers' and listeners' positive or negative face is called a Face Threatening Act (FTA). If this happens, for example in rebuking, the participants need to decide either to mitigate the threat by using certain strategies as shown in Figure or not [16].

This strategy is used for utterances considered not to be too threatening to the listener's face. The speaker utters directly without any platitude or softening act using positive or negative politeness strategies and it is mostly observed in close-distance relationship to state things clearly without any nonsense statements.

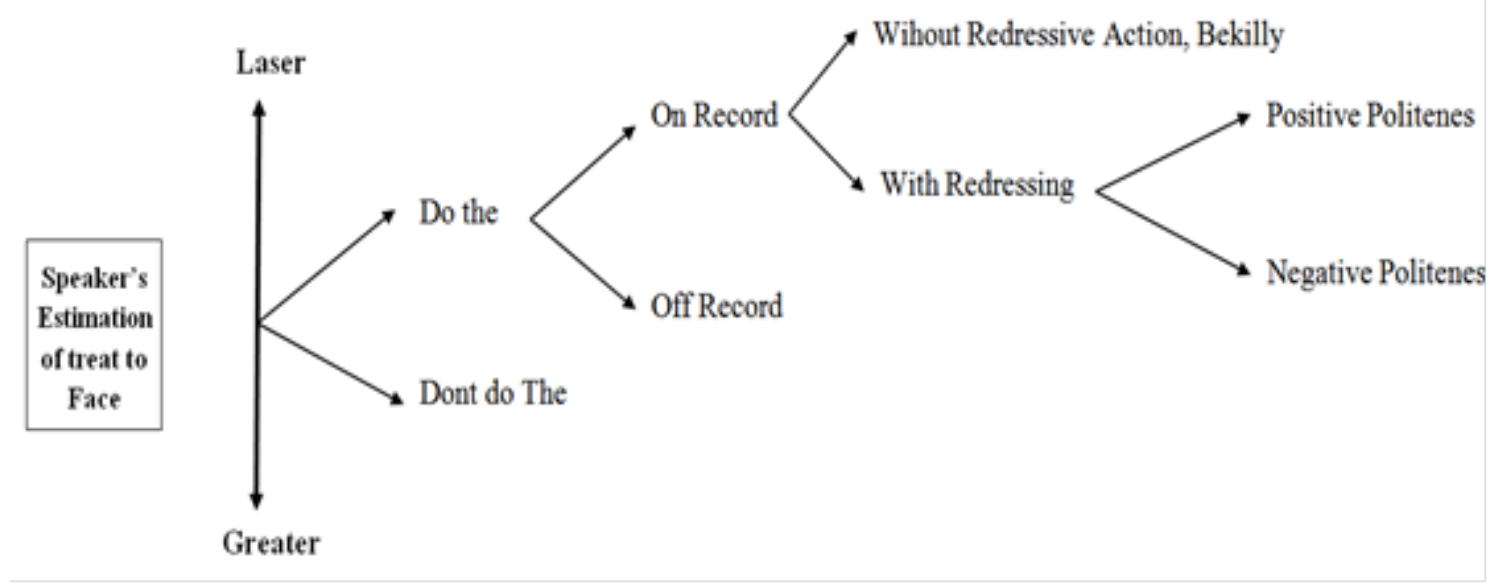

Figure 1. Brown and Levinson's Politeness Strategies Flow-Chart 2.3. Bald on Record Strategies (BORS) 
In this regard, the use of language in interactions in vocational student practice learning classes is interesting to be conducted. Based on the functional view of language, to understand the language interactions in classroom learning as communication events or interface speech events. Communication events marked the interaction between speakers and reciprocal speech partners are prominent where the form is determined by social goals [17].

\subsection{Positive Politeness Strategies (PPS)}

Positive politeness strategy is widely used between two friends, acquaintances, or even among a group of people with proximity. In conducting utterances, the speaker gives the impression of having the same wants with the listener to indicate a close distance relationship. Brown and Levinson [14] mentioned some of the criteria for these strategies to include (1) noticing the listener (his or her interest, wants, needs, goods), (2) increasing the listener's interest, approval and showing sympathy, (3) intensifying interest to the listener, (4) using in-group identity markers, (5) seeking an agreement, (6) avoiding disagreement, (7) presupposing or raising common ground, (8) joking, (9) showing concern for the listener's wants, (10) offering a promise, (11) being optimistic, (12) involving both the speaker and the listener in the speech act by using we or let's, (13) asking for reasons, (14) asserting reciprocity, and (15) giving respects to listener (good, sympathy, understanding, cooperation).

\subsection{Negative Politeness Strategies (NPS)}

Negative politeness strategy is used to save the listener's negative face by showing respect and distance. Brown and Levinson reported negative politeness strategies include (1) being conventionally indirect, (2) giving hedge, (3) being pessimistic, (4) minimizing imposition, (5) giving deference, (6) using apologies, (7) impersonalizing speaker and listener by avoiding the pronouns I and you, (8) stating FTA as a general rule, (9) nominate statements, and (10) going on record as incurring a debt, or as not indebting listener [14].

\subsection{Off Record Strategies (ORS)}

This is an indirect strategy to conduct FTA by allowing the listener to decide the meaning of the speakers' utterances. Brown and Levinson give some particular criteria to include (1) giving hints, (2) giving association clues, (3) presupposing, (4) understating, (5) overstating, (6) using tautologies, (7) using contradictions, (8) being ironic, (9) using metaphors, (10) using rhetorical question, (11) being ambiguous, (12) being vague, (13) over-generalizing by relating to the use of proverbs, (14) displacing the listener, and (15) being incomplete by using ellipsis [14].

\subsection{Not Doing the FTA?}

This strategy is usually used as the last option due to its high potential risk. It is implemented in a situation the speaker wants no reaction from the speech collaborates when a statement is uttered.

The review of related pieces of literature on speech act used for interaction in the academic section has been conducted by several previous researchers, both domestic and foreign [3]. The one conducted on polytechnic lecturers and students in Indonesia reported that directive speech act is mostly used between lecturers and students. Moreover, it was discovered that the interactional communication in the education, i.e., between teachers and students or lecturers and students, usually involves both verbal and nonverbal communication. In verbal communication, several speeches are exchanged between speakers and speech partners and various classroom interaction-based studies showed that these types of speech acts are widely used by teachers in oral interactions with students in the classroom according to [6], [10] [16], [18], [19], [20], [21].

This study focused on student's politeness attitudes towards lecturers in the context of verbal academic interactions. Therefore, an in-depth study of politeness was required to understand the problems between students and lecturers in academic activities on campus through utterance reflecting the indifference in a socio-pragmatic perspective [8]. Furthermore, several research works were found to have examined the directive politeness strategy and the similarities and differences between this research and previous relevant researches was conducted by [22], [23], [24].

\section{Research Methodology}

This research was conducted qualitatively using a pragmatic theory approach to determine the pragmatic aspects used by students during practical classes interaction. The researcher served as the main instrument of research through the active role played in collecting, identifying, selecting, and interpreting data [25].

The data used include warnings found in interactions between students in practical classes regarding violations or errors in practice procedures and was collected using Discourse Complete Test (DCT [26]. The research subjects were randomly selected 100 Pharmacy and 20 Automotive Study Program students doing practical in the laboratory of Polytechnic Indonusa of Surakarta. Tests on speech acts involving rebuke were given to the respondents in the form of a questionnaire with open answers and multiple comparisons method was used to retrieve data. At first, the observation of the rebuke context consisted of participants, 
situations, and topics after which the students were given entries to write the words mostly used to rebuke others. The data obtained was used to determine the pattern of speech acts and this was further tested for acceptance through the use of comments from other respondents and analyzed with reference to the relevant theory [27].

\section{Result and Discussion}

\subsection{Respondents Profile}

This questionnaire was designed to obtain open answer from the 120 respondents that actively participated in this study with the aim of obtaining real answers regarding strategies to rebuke among the students. The profile of the respondents is presented in the following table 1.

\subsection{The Type of Speech Act Used by Respondents}

There are several methods of classifying speech acts based on illocutionary effects as observed in two well-known taxonomies devised by Searle [1]. However, the classifications discussed in the literature review section were used and the results are presented in the following table 2.

Table 1. Respondents Profile

\begin{tabular}{|c|c|c|c|c|c|}
\hline \multicolumn{2}{|c|}{ Demographics } & $\begin{array}{c}\text { Pharmacy } \\
\text { Students }\end{array}$ & $\begin{array}{c}\text { Automotive } \\
\text { Students }\end{array}$ & Frequency & Percent (\%) \\
\hline \multirow{3}{*}{ Gender } & Male & 15 & 19 & 34 & $28,3 \%$ \\
\cline { 2 - 6 } & Female & 85 & 1 & 86 & $71,7 \%$ \\
\hline \multirow{3}{*}{ Semester } & III & 10 & 15 & 25 & $20,8 \%$ \\
\cline { 2 - 6 } & V & 90 & 5 & 95 & $79,2 \%$ \\
\hline \multirow{3}{*}{ Ethnic } & Javanese & 89 & 18 & 107 & $89,2 \%$ \\
\cline { 2 - 6 } & Non-Javanese & 11 & 2 & 13 & $10,8 \%$ \\
\cline { 2 - 6 } & $15-20$ years & 100 & 17 & 5 & $95,8 \%$ \\
\hline \multirow{3}{*}{ Language Usage Daily } & $20-25$ years & 2 & 5 & 28 & $23,2 \%$ \\
\cline { 2 - 6 } & Javanese & 23 & 2 & 12 & $10,0 \%$ \\
\cline { 2 - 6 } & Indonesian & 10 & 13 & 80 & $66,7 \%$ \\
\hline
\end{tabular}

Table 2. Respondents Speech Act Classification

\begin{tabular}{|c|c|c|c|c|c|c|c|c|}
\hline \multicolumn{2}{|c|}{ Information } & Assertive & Directive & Expressive & Commissive & Declaration & Silent & Total \\
\hline \multirow{2}{*}{ Respondents } & Pharmacy's Student & 5 & 35 & 51 & 3 & 0 & 6 & 100 \\
\cline { 2 - 9 } & Automotive's Student & 0 & 7 & 10 & 1 & 0 & 2 & 20 \\
\hline \multicolumn{2}{|c|}{ Frequency } & 5 & 42 & 61 & 4 & 0 & 8 & 120 \\
\hline \multicolumn{2}{|c|}{ Percent (\%) } & $4,17 \%$ & $35,00 \%$ & $50,83 \%$ & $3,30 \%$ & $0,00 \%$ & $6,70 \%$ & $100 \%$ \\
\hline
\end{tabular}


According to Table 2, the results showed 120 student speech acts were used including $5(4.17 \%)$ assertive, 42 (35\%) directive, 61 (50.83\%) expressive, 4 (3.30\%) commissive, and none was found to have used declaration speech acts. Therefore, the speech acts frequently used by students to reprimand for mistakes or SOPs violations during practice classes are assertive, directive, expressive, and commissive. However, the remaining 8 students representing $6.7 \%$ found not to have made any utterance include 2 that were silent without speech act and no action and 6 without utterance but with action. This study was conducted by analyzing the practising classroom interaction, particularly the speech acts generated by the student which include face-threatening acts and face-saving acts in speech event. The data in the form of words were the utterances produced by the students during the interaction.

The expressive's speech act of praising

Lecturer: "Tegar ... good!" (Lecturer while holding up his right thumb).

Situation context:

The lecturer gave praise to a student named Tegar who has completed the practice with a faster time and the results are good.

The expressive's speech act of the reprimanding Lecturer: "Who is charging batteries? Do you know what the battery ngecas procedure is? "
Situastion context:

There are students who have violated the procedure when the electrical practice, ie the battery menyi by not opening the cell cover. Otherwise, it will cause the battery to explode. This is very dangerous for safety. Therefore, the error of this procedure makes the lecturer angry.

\subsection{Politeness Strategy Used to Speech Act of Rebuke}

The second research question was to investigate the politeness strategies used in rebuke speech acts based on the politeness theory of Brown and Levinson [14] as previously stated in the literature review and the results obtained are stated in Table 3.

Table 3 shows no respondents have rebuked using face-threatening act and the most frequently used strategy was found to be the Bald on the Recording as observed in the 791 speech acts made by pharmacy students $(79.1 \%)$ and 107 by automotive students (53.5\%). This was followed by Positive Politeness with 116 from pharmacy students (11.6\%) and 60 from automotive students (30\%). The third strategy was negative politeness with 75 by pharmacy students (7.5\%) and 29 by automotive students $(14.5 \%)$ and the least politeness strategy used was the recording strategy (vague) with 18 speech acts by Pharmacy students (1.8\%) and 4 by Automotive students (2\%).

Table 3. Politeness Strategies used to the Speech Act of Rebuke

\begin{tabular}{|c|c|c|c|c|c|c|c|c|c|c|}
\hline \multirow{2}{*}{ Situation Context } & \multicolumn{2}{|c|}{ BORS } & \multicolumn{2}{|c|}{ PPS } & \multicolumn{2}{|c|}{ NPS } & \multicolumn{2}{|c|}{ ORS } & \multicolumn{2}{|c|}{ No FTA } \\
\hline & P'sS & A'sS & P'sS & A'sS & P'sS & A'sS & P'sS & A'sS & P'sS & A'sS \\
\hline 1 & 76 & 9 & 14 & 6 & 9 & 5 & 1 & 0 & 0 & 0 \\
\hline 2 & 81 & 11 & 9 & 7 & 10 & 2 & 0 & 0 & 0 & 0 \\
\hline 3 & 80 & 12 & 7 & 4 & 10 & 3 & 3 & 1 & 0 & 0 \\
\hline 4 & 77 & 11 & 11 & 5 & 8 & 3 & 4 & 1 & 0 & 0 \\
\hline 5 & 71 & 12 & 25 & 4 & 3 & 4 & 1 & 0 & 0 & 0 \\
\hline 6 & 80 & 13 & 9 & 5 & 8 & 2 & 3 & 0 & 0 & 0 \\
\hline 7 & 82 & 9 & 10 & 10 & 6 & 1 & 2 & 0 & 0 & 0 \\
\hline 8 & 85 & 10 & 10 & 6 & 4 & 4 & 1 & 0 & 0 & 0 \\
\hline 9 & 78 & 9 & 12 & 8 & 7 & 2 & 3 & 1 & 0 & 0 \\
\hline 10 & 81 & 11 & 9 & 5 & 10 & 3 & 0 & 1 & 0 & 0 \\
\hline Frequency & 791 & 107 & 116 & 60 & 75 & 29 & 18 & 4 & 0 & 0 \\
\hline Percent (\%) & $79,1 \%$ & $53,5 \%$ & $11,6 \%$ & $30 \%$ & $7,8 \%$ & $14,5 \%$ & $1,8 \%$ & $2 \%$ & 0 & 0 \\
\hline
\end{tabular}

P'sS: Pharmacy's Student

A'sS: Automotive's Student 
The result of analysis shows that the speech acts of directives have higher percentage. There are many sub-directives, such as, asking, ordering, advising, begging, and requesting. The discourse completion test is a written questionnaire in which a situation is given specifying the setting, the social distance between the participants, and their respective social status, followed by a brief dialogue with a blank for the respondent to provide a written response. The subjects are asked to write down what they think they would say in the described situations. This type is called open-ended elicitations. Another type of DCT provides a follow-up response after the blank which helps to cue the respondents as to the appropriate content of the response to be filled in. An example of the DCT is seen below.

Please write in the provided spaces whatever you would say in the following situation's context.

\section{Situation's Context}

In the practicum class, the students are not according to the procedure while observing bacterial colonies on colony counter devices. By the procedure, students see from the top through a magnifying glass. What would you say to him/her?

Your response:

Responses for example:

Student 33: Eh... ora ngono carane, kudune soko nduwur kene lho nontone.

Eh...bukan begitu caranya, harusnya melihat dari arah atas.

Eh ... that's not the way it should be, it should look from the top.

Student 46: Jane mudeng ora?

Sebetulnya kamu paham tidak?

Do you understand?

Student 54: Sek cah daripada salah koyok kae, moco sek module.

Bentar ah, daripada salah seperti itu mending baca modulnya dulu.

Wait a minute, rather than being wrong to read the module first.

The three examples are the students' responses to DCTs given to them. It should be noted that the data collected through a discourse completion test does not exactly reflect the richness and complexity of natural data. But it provides us with the stereotypical forms of language used in specific situations. Using DCT is appropriate for the initial stages of learning the communicative functions of language. It provides us with language that is less complex and less variable than natural data, but is similar enough to authentic language.

Based on the results of data analysis and discussions on classroom practicing interaction at the Polytechnic Indonusa of Surakarta, the realized illocutionary acts were: (a) directive, which is the act of commanding, (b) expressive, criticizing, rebuking, and reminding, (c) declarative, giving information, prohibiting, and deciding. On the basis of the observed speech acts, the more indirect utterances were expressed, the stronger pragmatic force on speaking partners. Meanwhile the students' expressed polite language with other fellow students in classroom interaction at the practical classroom were realized through the maxim of generosity, agreement, and tact maxim.

\section{Conclusions}

This study found the speech acts used among the students to be assertive, directive, expressive, and commissive and the results showed expressive speech act to be the most frequently used in the practical class. Moreover, despite the unchanging pragmatic perceptions, even after a lengthy stay in the country, the research strongly suggests education is essential for adaptation. The study also found that the use of rebuke, as an act or expression, to criticize someone's mistake has a high risk to threaten or invade the person's face.

The researcher suggests the next researchers to conduct studies by obtaining data from different contexts and situations. The researcher also suggests the next researcher to use more theories in analyzing the data, especially in analyzing how another subject of the study in different ages, relationships, or status can applied politeness in daily life.

\section{Acknowledgements}

This research was partially supported by Indonesian Ministry of Research, Technology and Higher Education. The author appreciates the efforts of the colleagues from Pharmacy and Automotive Diploma (D3), Polytechnic Indonusa of Surakarta for providing active participants for the research. 


\section{Appendix}

\begin{tabular}{|c|c|c|}
\hline \multirow{2}{*}{ No } & \multicolumn{2}{|c|}{ Situation Contexts } \\
\hline & Pharmacy Students & Automotive Students \\
\hline 1 & $\begin{array}{l}\text { The class in practicum starts. You see your friend is still busy } \\
\text { operating the cell phone, even though there is already a prohibition } \\
\text { that the cell phone must not be active when practicing in the } \\
\text { laboratory. What would you say her/him? }\end{array}$ & $\begin{array}{l}\text { In the workshop, your friend is still busy operating the } \\
\text { cellphone, even though the lecturer is explaining work } \\
\text { instructions. Would you say him? }\end{array}$ \\
\hline 2 & $\begin{array}{l}\text { You start the practicum. Your friend takes the ingredients by bringing } \\
\text { a bottle of Reagan everywhere. This is done so as not to stand in line, } \\
\text { even though it should not be done. What would you say to him/her? }\end{array}$ & $\begin{array}{l}\text { During the practice of charging the battery, a procedural } \\
\text { error occurred. Your friend forgot to unscrew the battery, } \\
\text { even though it was very dangerous. Would you say him? }\end{array}$ \\
\hline 3 & $\begin{array}{l}\text { The class practicing at the Pharmacy Laboratory, one of your friends } \\
\text { holds a dropper pipette not according to the procedure or the } \\
\text { wrongdoing to hold the dropper pipette. What would you say to } \\
\text { him/her? }\end{array}$ & $\begin{array}{l}\text { In the workshop, your friend forgets / doesn't wear a } \\
\text { wearpack. This certainly violates the rules. Would you say } \\
\text { him? }\end{array}$ \\
\hline 4 & $\begin{array}{l}\text { After finishing the laboratory work, you see your friend throwing } \\
\text { away bacterial growth media at the sink. What would you say to } \\
\text { him/her? }\end{array}$ & $\begin{array}{l}\text { During practice in the workshop, there is a friend of yours } \\
\text { who forgot to open the lock when lowering the car lift. } \\
\text { What would you say to him? }\end{array}$ \\
\hline 5 & $\begin{array}{l}\text { In the laboratory, there were students who did not bring cleaning } \\
\text { equipment to practice, even though they had been instructed at the } \\
\text { previous meeting. What would you say to him/her? }\end{array}$ & $\begin{array}{l}\text { In the workshop, your friend unlocks the bolt using the } \\
\text { wrong key What would you say to him? }\end{array}$ \\
\hline 6 & $\begin{array}{l}\text { The practicum is closing, there were students who did not give } \\
\text { labels/information on the chemicals made, even though all of them } \\
\text { were the same (liquid-clear). What would you say to him/her? }\end{array}$ & $\begin{array}{l}\text { Towards the end of the practice in the workshop, your } \\
\text { friend does not clean the workshop tools after use. What } \\
\text { would you say to him? }\end{array}$ \\
\hline 7 & $\begin{array}{l}\text { In the practicum class, there are students who do not carry and use the } \\
\text { PPE (personal protective equipment), which make in inaccurate results } \\
\text { suitable for contamination. What would you say to him/her? }\end{array}$ & $\begin{array}{l}\text { In the workshop and waiting for their turn, your friend does } \\
\text { other work outside the jobsheet. What would you say to } \\
\text { him? }\end{array}$ \\
\hline 8 & $\begin{array}{l}\text { In the practicum class, you see a friend who does not sterilize the } \\
\text { sterilizer before use, by not turning on the UV lamp for } 15-30 \text { minutes. } \\
\text { Your friend immediately wears it without going through the right } \\
\text { procedure. What would you say to him/her? }\end{array}$ & $\begin{array}{l}\text { During practice, your friend uses the compressor as a tool } \\
\text { to work on other friends, which is spraying the body. What } \\
\text { would you say to him? }\end{array}$ \\
\hline 9 & $\begin{array}{l}\text { In the practicum class, you see a friend who does not spray gloves with } \\
70 \% \text { alcohol and brings media to grow bacteria everywhere. What } \\
\text { would you say to him/her? }\end{array}$ & $\begin{array}{l}\text { During the practice in the workshop, your friend who from } \\
\text { the beginning entered jest constantly and not concentrate } \\
\text { on the practice What would you say to him? }\end{array}$ \\
\hline 10 & $\begin{array}{l}\text { In the practicum class, the students are not according to the procedure } \\
\text { while observing bacterial colonies on colony counter devices. By the } \\
\text { procedure, students see from the top through a magnifying glass. What } \\
\text { would you say to him/her? }\end{array}$ & $\begin{array}{l}\text { In the practice workshop Your friends who steal time off } \\
\text { without asking permission from the lecturer. What would } \\
\text { you say to him? }\end{array}$ \\
\hline
\end{tabular}

\section{REFERENCES}

[1] J. R. Searle, "Speech Act Theory and Pragmatics," 1980, pp. 221-232.

[2] F. M. Bosco, R. Angeleri, K. Sacco, and B. G. Bara, "Explaining pragmatic performance in traumatic brain injury: A process perspective on communicative errors," Int. J. Lang. Commun. Disord., vol. 50, no. 1, pp. 63-83, 2015.

[3] G. Mohammad, B. Alireza, and M. Shirin, "International Journal of Research Studies in Lang,” vol. 2, no. 4, pp. 4963, 2013.

[4] L. DeWaard, "The Pragmatics of Interaction,” J. Pragmat., vol. 44, no. 14, pp. 2104-2107, 2012.

[5] L. I. Z. Bills, "Politeness in Teacher-Student Dialogue in Mathematics : a Socio-Linguistic Analysis,” vol. 20, no. 2, pp. 40-47, 2017.

[6] R. Susanti, S. Sumarlam, D. Djatmika, and M. Rohmadi, "Responses to Caring Speech Acts: The Politeness Strategies of Indonesian Students in Academic Activities," in Proceedings of the Fourth Prasasti International Seminar on Linguistics (Prasasti 2018), 2018.

[7] J. L. Austin, How To Do Things With Words. London and New York: Oxford University Press, 1962.

[8] S. Simon and D. Dejica-Cartis, "Speech Acts in Written Advertisements: Identification, Classification and Analysis," Procedia - Soc. Behav. Sci., vol. 192, pp. 234-239, 2015.

[9] N. Vita Handayani, "the Use of Expressive Speech Acts in Hannah Montana Session 1,” Regist. J., vol. 8, no. 1, pp. 99-112, 2015.

[10] R. A. Van Compernolle, M. P. Gomez-Laich, and A. Weber, "Teaching L2 Spanish Sociopragmatics Through Concepts: A Classroom-Based Study,” Mod. Lang. J., vol. 100, no. 1, pp. 341-361, 2016.

[11] N. F. Al-Bantany, "The Use of Commissive Speech Acts and Its Politeness Implication: A Case of Banten Gubernatorial Candidate Debate,” Passage, vol. 1, no. Vol 1, No 2 (2013): October Graduation 2013, pp. 21-34, 2013.

[12] G. Yule, “The Study of Language 6th Edition,” Study Lang. 6th Ed., 2016.

[13] M. H. Katz, "Politeness theory and the classification of 
speech acts,” Work. Pap. Linguist. Circ. Univ. Victoria, 2015.

[14] P. and S. C. L. Brown, "Politeness: Some Universal in Language Usage,” London and New York: Routledge, 1987, pp. 311-323.

[15] M. Ryabova, "Politeness Strategy in Everyday Communication,” Procedia - Soc. Behav. Sci., vol. 206, no. November, pp. 90-95, 2015.

[16] S. M. Andi, "the Application of Politeness Strategies Among Teacher and Students in Classroom Interaction At Sma 1 Pamboang, Majene,” IDEAS J. English Lang. Teach. Learn. Linguist. Lit., vol. 6, no. 1, 2018.

[17] A. J. Matiki and N. N. Kgolo, “A Socio-pragmatic analysis of compliment responses among students at the University of Botswana,” J. Humanit., vol. 25, no. 2, pp. 62-89, 2017.

[18] L. Peng, F. Xie, and L. Cai, “A Case Study of College Teacher's Politeness Strategy in EFL Classroom,” Theory Pract. Lang. Stud., vol. 4, no. 1, pp. 110-115, 2014.

[19] W. Stadler, "Teaching and Testing Sociopragmatics in the Russian Language Classroom,” Athens J. Philol., vol. 2, no. 3, pp. 149-162, 2018.

[20] S. M. Basra and L. Thoyyibah, "a Speech Act Analysis of Teacher Talk in an Efl Classroom,” Int. J. Educ., vol. 10, no. 1, p. 73, 2017.

[21] R. Susanti and M. Rohmadi, "Investigation of Students , toward Environmental Awareness through Responses of Caring Speech Acts: A Case Study of Polytechnic' s Student in Surakarta , Indonesia,” in Wol2SED 2018, 2019.

[22] Wafa \& Indrawati Vahmita, "Directive Illocutionary Act on English Teacher in Elementary School Sukoharjo 3 Probolinggo (Pragmatics Study),” Metathesis, vol. 1, no. 1, pp. 119-129, 2017.

[23] M. Thamrin, "Ekspresi Tindak Direktif dalam Interaksi Kelas Bengkel Jurusan Teknik Mesin Politeknik Negeri Malang,” LITERA, vol. 9, no. April, pp. 92-101, 2010.

[24] L. Tri Budiasih, "Illocution on Speech Acts of Foreign Students in Indonesian Learning,” Parol. J. Linguist. Educ., vol. 6, no. 2, p. 41, 2018.

[25] L. M. Beebe and M. Clark Cummings, "Natural speech act data versus written questionnaire data: How data collection method affects speech act performance,” no. 1991, pp. 6588, 2009.

[26] E. Sweeney and Z. Hua, “Discourse Completion Tasks,” in Research Methods in Intercultural Communication: A Practical Guide, no. Chapter 14, John Wiley \& Sons Inc, 2015, pp. 212-222.

[27] F. Aufa, “The Use of Discourse Completion Task (DCT) As Explicit Instruction On Indonesian Efl Learners’ Production of Suggestion Acts,” J. English Educ., vol. 5, no. 2, pp. 2143, 2016. 